INTRODUCTION

\title{
The Future is Now
}

\author{
Reflections on Art, Science, Futurity
}

\author{
Charlene Villaseñor Black \\ Mari-Tere Álvarez
}

What can I see more than I have already seen?

-Sancho Panza

Thou hast seen nothing yet.

-Don Quixote

- Miguel De Cervantes, DON QUixote DE LA MANCHa, CHAPTER 11, BOOK 1, PART $1(1605)^{1}$

The Renaissance was a period defined, one could argue, by visions of the future. Petrarch's Letter to Posterity (ca. 1372) and Dante's Divine Comedy (ca. 1308-20) represent early manifestations of this concern with the future, fame, and posterity, followed by Renaissance historian and humanist Leonardo Bruni's histories and biographies of the 1440 s and Giorgio Vasari's celebrated Lives of the Most Excellent Painters, Sculptors, and Architects of 1550. At the same time, European explorers, merchants, soldiers, and missionaries traversed the globe in search of new lands to conquer, new natural resources to acquire, and new souls to convert to Christianity. Like Renaissance humanists, they, too, were fueled by visions of the future, coupled with imperial ambition. The Renaissance thus gave rise to the Scientific Revolution and the greatest cultural flowering in the West since ancient times, along with European imperialism. Such ambition inspired ingenuity.

This book focuses on the intersection of Renaissance art, ingenuity, and futurity. The essays represent a fertile variety of fields - art history, literature studies, social history, the history of science and technology, the history of medicine, intellectual history, and material science studies. The authors are scholars in the 
humanities, sciences, social sciences, and the arts. Our goal in these essays is to examine the connections among the new science, artistic rebirth, and European imperialism in the overlapping worlds of science, technology, and art, with the ultimate objective of transcending disciplinary specialties to forge new, more productive dialectical discourses.

The topic of Renaissance art and science is not entirely new, having emerged in the 1980 os and 1990 os with the advent of interdisciplinary studies. At that time, a number of symposia and resulting publications began discussion of the interactions between science and the arts from the Renaissance to the twentieth century. ${ }^{2}$ In the 1980 os, the journal Leonardo published series of bibliographies on the general topic of science and the arts. ${ }^{3}$ A 1995 exhibition in London examined connections between art and medicine, putting historical medical devices in dialogue with the work of contemporary art. ${ }^{4}$ The essays in Renaissance Futurities, in contrast to these earlier publications, contextualize the history of art and science in the specific historical, political, and artistic moment of the Renaissance, supplemented by significant new primary source research.

One scholar, in particular, has shaped the study of the topic at hand: Martin Kemp, the leading authority on science and art in the Renaissance and a major expert on Leonardo da Vinci. Kemp has training in both art history and natural science. An early and influential text is his 1990 study of optics, The Science of Art: Optical Themes in Western Art from Brunelleschi to Seurat, which focuses on optics and one-point perspective. ${ }^{5}$ In a more recent 2006 publication, Kemp examines intuition, a subject also broached in an essay in this volume by a scientist, a medical doctor, and an art historian (Gharib, Wells, Álvarez). In Seen/Unseen: Art, Science, and Intuition from Leonardo to the Hubble Telescope, Kemp examines how scientists and artists visualize and represent the world, from Renaissance Italy to contemporary photography. ${ }^{6}$ In a recent publication assembled to honor the illustrious Kemp's career, Assimina Kaniari and Marina Wallace collected essays also focused on intuition. Various authors theorize how structural intuition, a concept that Kemp first articulated, links the way scientists and artists think. ${ }^{7}$ Kemp's many publications have stimulated much new research and have been formative for the scholarship in this volume. ${ }^{8}$ Inspired by his foundational work, authors in Renaissance Futurities look concretely at the interactions between art and science; they ponder specific inventions, in conjunction with Renaissance notions of futurity and new theories of temporality.

The work in this volume also builds on the scholarship linking the emergence of Early Modern science to craftsmen, workshop practices, and the artist-engineer. Key foundational studies include investigations by Viennese historian Edgar Zilsel (1891-1944) and Italian philosopher Paolo Rossi Monti (1923-2012). ${ }^{9}$ In 1985, Katharine Park highlighted the importance of artisans in the emergence of medicine in early Renaissance Florence. ${ }^{10}$ In 1994, William Eamon, one of the contributors to Renaissance Futurities, published Science and the Secrets of Nature, docu- 
menting the emergence of methods for scientific experimentation among artisanal craftsmen. ${ }^{11}$ More recently, Pamela H. Smith proposed "artisan epistemology" as a foundation of Early Modern science, a way of understanding the world based on practice, not theory. She describes the important role played by artisans and their workshops, who, as they created new art objects, developed new technologies through experimentation. ${ }^{12}$

Pamela H. Smith's later work engages the material turn in the humanities, arguing for the importance of transdisciplinary work that brings together the history of science and the history of art. ${ }^{13}$ Other scholars whose work lies at this intersection include Sven Dupré and Alex Maar, currently involved in a project investigating Early Modern art, science, and ingenuity. ${ }^{14}$ Volume contributor Claire Farago addresses this same intersection-between artists' workshop practice, the new science, and ingenuity-in the concluding chapter. Finally, a great deal of new research focusing on the materiality of artworks, arising from technical art history, brings together art historians, conservation scientists, and museum curators. ${ }^{15}$

Recent developments in the history of science in Spain and the Iberian empire have also been fundamental to this volume. The earliest literature tracing the emergence of the Scientific Revolution in Europe, from 1543, the year that Copernicus published De revolutionibus orbium coelestium (On the Revolution of the Heavenly Spheres), to the Enlightenment, completely neglected Spain and its empire, due to the "Black Legend." According to Eamon and others, these negative stereotypes, dating to the colonial era and traceable to imperial rivals, such as England, portrayed Spain as backward and repressive. ${ }^{16} \mathrm{~A}$ flurry of new scholarship, much of it produced after the 1992 quincentenary, contests this rhetoric by demonstrating the importance of scientific developments in Spain and its vast imperial empire during the Scientific Revolution, from colonial contact to the Enlightenment. Key historians include Eamon, Paula S. De Vos, Jorge Cañizares-Esguerra, and Daniela Bleichmar. ${ }^{17}$

Conceptions of futurity are central to this undertaking. Our concern is inspired by the Renaissance itself, with its interest in fame and posterity. By "futurity" we denote theorizations of the future, prospective events, as well as an attitude or mode of thinking about the world. The term first appears in Shakespeare in 1603, in The Tragedy of Othello, the Moor of Venice, as Álvarez points out in her essay. Temporality has been an important theme in recent works in Renaissance studies, such as Alexander Nagel and Christopher Wood's Anachronic Renaissance, which influenced several of the essays. That groundbreaking book suggests that Renaissance artworks are "anachronic"; that is, they reflect temporal instability, because they encode references to Europe's multiple pasts, an example of what Nagel and Wood describe as time "folding" over on itself. ${ }^{18}$ Jonathan Goldberg's suggestion that Europe had multiple histories, an idea influenced by queer theory, opens up standard Renaissance histories to new interpretations. ${ }^{19}$ As art historian Keith Moxey contends in his recent book Visual Time: "[H]istorical time is heterochronous rather than monochronous." ${ }^{20}$ 
Futurity is a mode of thinking bound up with European conquest and imperialism, a stance adopted in several of the essays (Álvarez and Eamon, for example) and in much decolonial thinking. We understand "decolonize" as drawn from "decolonial," as opposed to colonial, or coloniality, or "the coloniality of power," to use a phrase employed by Aníbal Quijano in 2000 and Walter Mignolo in 2011. ${ }^{21}$ Decolonial approaches challenge Eurocentrism, and Eurocentric notions of universality; they make visible Foucault's history of power as they perform what Mignolo calls "epistemic disobedience."22 Mignolo's "epistemic disobedience" is elaborated from postcolonial theorist Gayatri Chakravorty Spivak's "epistemic violence." ${ }^{23}$ According to Spivak (and others, such as Edward Said), the subaltern, defined as former colonial subjects, are othered and silenced by Eurocentric discourse, the latter cloaked as universalizing. Mignolo's call for epistemic disobedience is particularly useful to unsettle art historical assumptions that some art is of higher quality than other art or that we should respect national and chronological borders. His approach thus encourages intellectual rebellion against accepted discourse about the Renaissance. ${ }^{24}$ This gives rise to important questions: Which histories are authorized, and who is empowered to narrate them?

Furthermore, looking at the past and how we describe it also affects our future. Futurity, as distinct from the future, "will always retain the essential structure of a promise and as that which can only arrive as such, as to come," according to Jacques Derrida, an idea that frames co-editor Álvarez's essay. ${ }^{25}$ Literary scholar Amir Eshel writes that "[f] uturity marks the potential of literature to widen the language and to expand the pool of idioms we employ in making sense of what has occurred while imagining whom we may become. . . Futurity marks literature's ability to raise, via engagement with the past, political and ethical dilemmas crucial for the human future. In turning to the past, the works here keep open the prospect of a better tomorrow." ${ }^{26}$ Our conceptualization of "futurity" is also conditioned by theorizing in the realm of ethnic studies, especially recent work on Afro and Chicana/o/x futurisms. ${ }^{27}$ Futurist scholars, writers, activists, and artists in ethnic studies posit new, more just futures for people of color, alternative futurisms inspired by non-Western notions of temporality, as they simultaneously question Eurocentric constructions of history, a topic addressed by de Armas in chapter 4 and co-editor Villaseñor Black in the conclusion to chapter 7. A recent book by Matthew D. O'Hara takes notions of futurity back to colonial Mexico, employing archival documents to attempt to reconstruct a notion of "futuremaking" in colonial times. ${ }^{28}$

The chapters in Renaissance Futurities are rich and varied, at the cutting edge of the humanities, medical humanities, scientific discovery, and avant garde artistic expression. Authors examine developments in Renaissance art and science in Spain and the Americas, England, the Netherlands, Germany, France, Italy, China, and the Middle East between the fifteenth and mid-seventeenth centuries. By including the work of humanities scholars and scientists from Europe and the 
United States, we arrive at parallax understanding of art and science in the Renaissance. Comparative and transdisciplinary analysis of primary sources such as artists' notebooks, royal correspondence, and scientific treatises has already revealed the clear links among art, science, global trade, and even daily life at the time.

In chapter 1, "Moon Shot: From Renaissance Imagination to Modern Reality," volume co-editor Mari-Tere Álvarez demonstrates the connections between European imperialism and futurity in her examination of Early Modern tales of space travel. Employing visual art-such as maps and medals, as well as a play by John Lyly, a novel by Juan Maldonado, and a satirical poem about the Jesuits by John Donne-Álvarez draws attention to Early Modern fantasies of space travel and their connection to Spanish conquests in the Americas.

In chapter 2, "Machines in the Garden," Jessica Riskin contrasts twenty-firstcentury anxieties about machines' potential to encroach upon or replicate human consciousness with Renaissance fascination with automata, machines that imitated human beings. Through copious historical data, she documents the existence throughout Europe of animated figures of Christ on the cross, flying angels, soaring Virgin Marys; lifelike mechanical animals, dragons, birds, nymphs, satyrs, and mythological figures; and elaborate waterworks on palace grounds designed to trick and entertain. For example, Leonardo da Vinci created an automaton lion in 1515; Juanelo Turriano designed mechanical automata to amuse Charles V; and Tommaso Francini delighted the young Louis XIII with elaborate hydraulics in the gardens at Saint-Germain-en-Laye. The Catholic Church was the major patron of these mechanical creations, and not surprisingly, automata played a role in conversion. Riskin also examines the Early Modern proliferation of texts about creating automata, including Le diverse e artificiose machine (1588) by Agostino Ramelli and Salomon de Caus's Les raisons des forces mouvantes avec diverses machines tant utiles que plaisantes of 1615 .

In chapter 3, "Inventing Interfaces: Camillo's Memory Theater and the Renaissance of Human-Computer Interaction," Peter Matussek addresses Renaissance ideas about memory theaters and their links to current developments in humancomputer interaction, or HCI. He traces strategies employed today back to Giulio Camillo's memory theater, described in Camillo's text L'idea del theatro, posthumously published in 1554, as well as to Robert Fludd's Ars Memoriae of 1619. As in computer interfaces today, Camillo's memory theater called upon spectators to actively acquire and recall knowledge. This required viewers to combine ars memoria, a set of strategies derived from Neoplatonic thought, with the newer ars combinatoria, which, Matussek suggests, is the current model for twenty-firstcentury HCI. He additionally connects this fascination with memory theaters to new media-artists, including Robert Edgar, Bill Viola, Kate Robinson, and Ronald T. Simon. Although Camillo's theater does not actually survive, Matussek attempts to re-create it, using surviving textual descriptions, the architecture itself, and a painting by Titian, his Allegory of Prudence, which once adorned the space. 
Chapter 4, "Futurities, Empire, and Censorship: Cervantes in Conversation with Ovid and Orwell," by Frederick A. de Armas, addresses censorship, another current concern, and links it, also, to the Renaissance, in a close examination of Cervantes's masterpiece, Don Quixote de la Mancha. Don Quixote, the first modern novel, was published in 1605 and 1615, and de Armas reads it in dialogue with Ovid and George Orwell. According to de Armas, "latent futurity" was central to Spain's Golden Age, evident in the country's imperial ambitions, and central to Cervantes's novel. His consideration of the mechanisms of imperial control in the Spanish Empire lead to close analysis of self-censorship, or steganography, in the novel; these were tactics to conceal and hide, including whimsy, ugliness, and fragmentation, all strategies employed to camouflage. The figure of Don Quixote, the failed, impossible knight who fashions his own future, prompts reconsideration of his figure from the viewpoint of queer temporality. Finally, de Armas outlines strategies of resistance as seen in Don Quixote as inspiration in our current political climate.

Three of the authors-a medical doctor, a professor of aeronautics, and an art historian-are engaged in projects centered on Leonardo da Vinci and Renaissance futurities; their research forms the core of chapter 5, "Anticipating the Future: Leonardo's Unpublished Anatomical and Mathematical Observations." The first part closely examines the artist's anatomical drawings and their prediction of future developments in medicine; the second investigates Leonardo's mathematical equations and their anticipatory relationship to differential calculus. Francis Wells carefully studies Leonardo's drawings of the heart to demonstrate their prescient nature. Many of the discoveries notated in drawings and accompanying texts would not be known again until the twentieth century. Leonardo, for example, wrote the first description of coronary atherosclerosis, in 1507-8. His dissections reveal the heart's internal structures, including how the heart valves work, and the connections between the lungs and heart. Wells recreated the dissections performed to confirm Leonardo's findings. The scientific approach of Leonardo's drawings, which showed the artist experimenting with possibilities, anticipates modern scientific method, by presenting evidence of the tight links between art and science in the Renaissance. In the second half of chapter 5, focused on Leonardo's mathematical equations, Morteza Gharib builds on Martin Kemp's work on analogy in Kemp's Seen/Unseen as a tool to decipher natural laws, looking specifically at Leonardo's investigations into ballistic trajectories and the law of gravity. By closely studying Leonardo's drawings and annotations in his notebooks, including the Arundel manuscript and the example in Madrid, Gharib demonstrates Leonardo's understanding of natural laws purportedly not discovered until the seventeenth century. His trajectories and profiles of falling objects illustrate the equations of motion described in the seventeenth century by René Descartes, Isaac Newton, and Gottfried Leibniz. His drawings of parabolas in the Codex Madrid illustrate his experiments try- 
ing to deduce the law of gravity. One drawing seems to describe "the parabolic nature of ballistic trajectories," a discovery ascribed to Galileo.

Chapter 6, "Medicine as a Hunt: Searching for the Secrets of the New World," by William Eamon, suggests that Early Modern Spanish imperialism fostered the creation of a new model for the future of science and medicine-the hunt, or venatio, for nature's secrets. This chapter assesses the various expeditions to the Americas, such as King Philip II's sponsorship of court physician Francisco Hernández to travel there to identify and collect botanical specimens, described by Eamon as "the most ambitious organized hunt for new medicinal plants ever attempted." This chapter examines a number of other important figures: Gonzalo Fernández de Oviedo; Jesuits José de Acosta, Bernabé Cobo, Juan Eusebio Nieremberg, and Athanasius Kircher; plus Giambattista Della Porta, Sir Francis Bacon, and Nicolás Monardes. Building upon the previous work of Carlo Ginzburg, Eamon suggests that "the hunt" encapsulates a new evidential and conjectural paradigm, one that rejects previous Platonic models reliant on ancient authorities. Thus, it fosters the creation of a radical new future for medicine. The model of the "hunt" is still much in use in medical research: Consider the search for a cancer cure.

Chapter 7, "The Half-Life of Blue," by volume co-editor Charlene Villaseñor Black, considers blue as the color of the future as it considers why Spanish artists would employ blue pigments that degraded within decades of use when other more stable pigments were available. Does the use of these blue pigments upset accepted notions about Renaissance temporality and claims to fame and posterity? Contextualized within Early Modern quests for new sources of blue pigments, this essay examines the semiotic value of blue in Spain and its associations with the culture of al-Andalus in the Iberian Peninsula. Inspired by the notion that Europe was home to multiple histories, as theorized by Jonathan Goldberg, this essay suggests that Spain's interest in blues during the Renaissance was a prediction of what would transpire in the rest of Europe. The fashion for blue in Spain was based in its Islamic past, including knowledge of technological advances that made possible the creation of desired blue pigments.

This anthology closes with an essay by Claire Farago on Early Modern ingenuity and artistic invention, “Ingenuity' and Artists' Ways of Knowing." The author performs a close transverse analysis of this concept (ingegno), in a study of important texts on art and imitation by such luminaries as Cennino Cennini, Leonardo da Vinci, Giorgio Vasari, Filarete, and Leon Battista Alberti. Ingegno is closely associated with Renaissance conceptions of great genius and thus of central importance to studies of the period. Her findings are significant, including the observations that the categories of art and science were more fluid during the Renaissance than they are now and were closely linked by practical knowledge. She demonstrates this through her close study of how certain artistic skills and procedures - imitation, for example - were passed down orally in workshops. Furthermore, because Leonardo considered the painter a mirror of nature, painting in 
the Renaissance was therefore science, a break with Medieval conceptions of visual images as embodiments of the sacred. These new conceptions of art, particularly an art based in mimesis, or naturalism, were not "innocent," as Farago points out. They served as tools of European imperialism.

A primary goal of this book is to break down disciplinary divisions and foster new transdisciplinary dialogues on the topic of Renaissance art, science, and futurity. The methodologies of humanities scholars are combined with research approaches from aeronautics, medicine, artificial intelligence, computers, mathematics, chemistry, and natural science. Embedded here, too, is a belief in the value of the past. Our concern is not solely with how the Renaissance predicted the future, but also with how knowledge of the past can help us in the contemporary moment, by providing strategies to combat challenges to come. We are inspired by the fantastic creations of Leonardo da Vinci-his flying machines or robots or weapons, which were perceived during his lifetime as fantastic, even hallucinatory. Today, we similarly assess the future worlds of later writers such as Jules Verne, $\mathrm{H}$. G. Wells, and contemporary science-fiction authors. But many of the inventions of the Renaissance have now come to fruition. To quote Don Quixote: "Thou hast seen nothing yet."29 